\title{
A RESPONSABILIDADE CIVIL NA REMOÇÃO DE NAUFRÁGIOS
}

\section{THE CIVIL LIABILITY APPLICABLE TO THE WRECKS REMOVAL}

\section{INGRID ZANELLA ANDRADE CAMPOS}

Professora do Programa de Pós-Graduação em Direito da Faculdade Damas da Instrução Cristã. Doutora e Mestre pela Direito na Universidade Federal de Pernambuco (UFPE). Professora Adjunta da Universidade Federal de Pernambuco (UFPE). Auditora Ambiental Líder. Perita Ambiental Judicial. Coordenadora e Professora da Pós-Graduação em Direito Marítimo, Portuário e do Petróleo da UNINASSAU/PE. Professora da especializações em Direito Marítimo, Portuário e Ambiental da UNISANTOS/SP, Faculdade de Direito de Vitória/ES, UNIVALI/SC e UFRN. Presidente da Comissão de Direito Marítimo, Portuário e do Petróleo da OAB/PE. Membro da Comissão de Meio Ambiente da OAB/PE. Oficial do Conselho da Ordem do Mérito Naval/Marinha do Brasil. Advogada no escritório Zanella Advogados \& Consultores, em Recife/PE.

\section{RESUMO}

Objetivo: $O$ estudo objetiva compreender a capacidade da mente humana de criar falsas memórias e sua influência e incidência na prova testemunhal do processo penal. Aponta para a alta incidência de casos de falsas memórias no processo penal brasileiro. Assim, o objetivo é apresentar algumas medidas eficazes para mitigar a presença de faltas memórias durante a instrução em casos penais.

Metodologia: Para atingir os fins esperados, a metodologia utilizada será documental, utilizando-se o método dedutivo, com caráter bibliográfico. Utilizou-se os métodos descritivo, bem como revisão bibliográfica.

Resultados: Apresentam-se algumas medidas capazes de diminuir a presença de falsas memórias em testemunhos durante a instrução, de maneira a minimizar o impacto negativo na resolução dos casos penais, de falhas cognitivas usuais que caracterizam os processos mnemônicos. 
Contribuições: A contribuição do presente trabalho é reconhecer a relevância do trabalho multidisciplinar nos estudos das falsas memórias, na capacitação dos profissionais de Direito acerca deste aspecto e na integração de profissionais de outras áreas no ambiente do processo criminal, para buscar medidas e soluções que possam efetivamente diminuir o efeito das falsas memórias no processo penal, colaborando diretamente para decisões mais precisas na solução das matérias vinculados ao direito penal.

Palavras-chave: Processo penal; prova testemunhal; falsas memórias.

\section{ABSTRACT}

Objective: The study aims to understand the capacity of the human mind to create false memories and its influence and impact on the testimonial evidence of criminal proceedings. It points out the high incidence of cases of false memories in the Brazilian criminal process. The objective is to present some effective measures to mitigate the presence of missing memories during instruction in criminal cases.

Methodology: To achieve the expected purpose, the methodology used is documentary, using the deductive method with bibliographic character. Descriptive methods were used, as well as a literature review.

Results: Some measures capable of reducing the presence of false memories in testimonies during instruction are presented, in order to minimize the negative impact on the resolution of criminal cases of usual cognitive flaws that characterize mnemonic processes.

Contributions: The contribution of the present paper is to recognize the relevance of multidisciplinary work in the study of false memories in the training of law professionals on this aspect and in the integration of professionals from other areas in the criminal process environment to seek measures and solutions that can effectively reduce the effect of false memories in the criminal process, collaborating directly for more precise decisions in the solution of matters related to criminal law.

Keywords: Criminal proceedings; testimonial evidence; false memories.

\section{INTRODUÇÃO}

Atualmente, o Direito Marítimo está intimamente ligado ao desenvolvimento econômico e social regional, nacional e internacional. Ademais, o reaquecimento da 
indústria naval em face da construção de plataformas petrolíferas e de novos estaleiros, bem como do desenvolvimento da navegação de cabotagem fará com que cada vez mais surjam novas demandas especializadas envolvendo o Direito Marítimo.

O Brasil é um país maritimamente privilegiado, conta com uma costa de 8,5 (oito vírgula cinco) mil quilômetros navegáveis, onde o transporte marítimo responde, atualmente, por mais de $80 \%$ (oitenta por cento) do comércio mundial de mercadorias e se constitui como fator imprescindível na globalização.

O transporte aquaviário se consubstancia, então, como um fator fundamental na economia mundial, além de estar inteiramente ligado a questões ambientais e sociais.

Parte da doutrina divide os modais de transporte em: aquaviário, terrestre e aéreo. Por sua vez o transporte aquaviário compreende todo e qualquer tipo de transporte que envolva vias aquáticas e pode ser dividido em: marítimo, fluvial e lacustre, realizados, respectivamente, em mares e oceanos, rios e lagos.

A Constituição da República Federativa do Brasil de 1988, através da Emenda Constitucional oㅜ 7, de 15 de agosto de 1995 deu nova redação ao parágrafo único, do artigo 178 (cento e setenta e oito), que passou a permitir o uso de bandeiras estrangeiras na navegação de cabotagem no Brasil, desde que afretadas por empresas brasileiras.

Dessa forma o parágrafo único, do supracitado artigo, passou a ter a seguinte redação: "Na ordenação do transporte aquático, a lei estabelecerá as condições em que o transporte de mercadorias na cabotagem e a navegação interior poderão ser feitos por embarcações estrangeiras."

A abertura constitucional à navegação interior por embarcações estrangeiras foi decorrência da afirmação do Estado democrático de direito, igualmente chamado de Estado Constitucional, com a soma das liberdades conquistadas com o Estado Liberal mais a busca pela justiça social, do Estado Social (GOMES, 2008, p.20).

Nesse diapasão, destacam-se a Lei de Ordenação do Transporte Aquaviário no 9.432/1997 e a Lei de criação da Agência Nacional de Transportes Aquaviários (Antaq) e do Conselho Nacional de Integração de Políticas de Transportes (CONIT), Lei no 10.233, de 05 de junho de 2001. 
A Lei o 9.432/1997 veio para regulamentar o artigo 178 da Constituição Federal e permite a abertura do mercado a embarcações estrangeiras, desde que afretadas por embarcações de bandeira nacional (EBN), quando da inexistência ou indisponibilidade de embarcações de bandeira brasileira.

A Agência Nacional de Transportes Aquaviários (Antaq) atua na navegação fluvial, lacustre, de travessia, de apoio marítimo, de apoio portuário, de cabotagem e de longo curso; nos portos organizados; nos terminais portuários privativos e no transporte aquaviário de cargas especiais e perigosas (art. 23, Lei n.․⒑233/2001).

A real preocupação com os danos e responsabilidades advindas de acidentes marítimos está, inclusive, embasada no aumento significativo da ocorrência desses, posto que, em 2017, os acidentes com embarcações, no Brasil, aumentaram 12,63\%. Segundo a Marinha do Brasil, de janeiro a agosto de 2017 foram registrados 107 naufrágios, contra 95 casos no mesmo período de 2016 (BRASIL, 2017).

De acordo com as estatísticas, $72 \%$ dos casos de naufrágios ocorreram por imprudência, imperícia ou negligência. Apesar do aumento de naufrágios nos primeiros oito meses de 2017, a Marinha informa que entre 2015 e 2016 os registros diminuíram. Em 2016, foram 898 contra 998 em 2015 (BRASIL, 2017).

É possível constatar, através da tabela infra, o número de naufrágios ocorridos entre o ano de 2000 a 2015 (BRASIL, 2016), vide:

\begin{tabular}{|c|c|c|c|c|c|c|c|c|c|c|c|c|c|c|c|}
\hline 2000 & 2001 & 2002 & 2003 & 2004 & 2005 & 2006 & 2007 & 2008 & 2009 & 2010 & 2011 & 2012 & 2013 & 2014 & 2015 \\
\hline 83 & 79 & 83 & 92 & 87 & 101 & 89 & 114 & 120 & 124 & 151 & 155 & 135 & 171 & 160 & 186 \\
\hline
\end{tabular}

A Diretoria dos Portos e Costas (DPC) divulga os Quadros Estatísticos de Inquéritos e Acidentes da Navegação (IAFNs), incluindo diversos fatores, entre esses a estatística de acidentes da navegação por natureza, onde os acidentes com naufrágio totalizam 42,29\% dos acidentes (BRASIL, 2018).

Constata-se que quase $50 \%$ dos acidentes marítimos foram naufrágios, criando uma situação altamente complexa, envolvendo tratativas com empresas habilitadas, para contenção de possíveis vazamento de óleo, remoção de óleo e carga no interior da embarcação, para, ao final, analisar a melhor saída possível. Assim, a identificação da melhor estratégia pode envolver a recuperação da embarcação, 
através da remoção do caso naufragado, ou o naufrágio em local autorizado pela Autoridade Marítima e até o abandono do casco no local do naufrágio.

A solução segura e correta para um acidente como este não é algo célere e sem qualquer planejamento, além de complexo, envolve fatores e condições de natureza, estudos, planejamento para evitar ou minimizar danos ao meio ambiente, razão pela qual envolve diversos atores e campos de responsabilidade.

Portanto, o objetivo principal deste trabalho é a problemática subjacente à definição da responsabilidade pela remoção dos cascos naufragados, possibilitando uma maior proteção da área marítima, evitando danos ambientais e pugnado pela manutenção da segurança da navegação.

\section{ACIDENTES MARÍTIMOS}

A Convenção Montego Bay, em seu art. 1ํ, Decreto $n^{\circ} 1.530$, de 22 de junho de 1995, no artigo 221, ao tratar das medidas para evitar poluição ambiental resultante de acidentes marítimos, entende que acidente marítimo significa um abalroamento, encalhe ou outro incidente de navegação ou acontecimento a bordo de uma embarcação ou no seu exterior, de que resultem danos materiais ou ameaça iminente de danos materiais à embarcação ou à sua carga.

No Brasil, a Lei $n^{\circ} 2.180$, de 05 de fevereiro de 1954, que dispõe sobre o Tribunal Marítimo, traz um rol exemplificativo dos acidentes da navegação, citando os seguintes: abalroamento ou abalroação, naufrágio, colisão, encalhe, varação, alijamento, incêndio, água aberta e arribada.

Por sua vez, o Código Comercial Brasileiro (Lei n 556 , de 25 de junho de 1850) regula os fatos da navegação no Título IX, do naufrágio e salvamento, Título $X$, das arribadas forçadas, Título XI, do dano causado por abalroação, Título XII, do abandono, e, por fim, no Título XIII, das avarias.

Neste interim, destaca-se a NORMAM 9/DPC (Normas de Autoridade Marítima para Inquéritos Administrativos sobre Acidentes e Fatos da Navegação 
(IAFN) e para Investigação de Segurança dos Acidentes e Incidentes Marítimos (ISAIM), e traz as definições dos acidentes e fatos da navegação, a seguir destacados.

Primeiramente, a abalroamento ou abalroação deve ser entendido como choque entre embarcações ou seus pertences e acessórios. De acordo com o Código Comercial vigente, art. 749, sendo um navio abalroado por outro, o dano inteiro causado ao navio abalroado e à sua carga será pago por aquele que tiver causado a abalroação, se esta tiver acontecido por falta de observância do regulamento do porto, imperícia, ou negligência do capitão ou da tripulação (CAMPOS, 2017, p.259-290).

De acordo com o mencionado código, art. 752, a regra é que o abalroamento seja caracterizado como avaria simples, assim todas as perdas resultantes de abalroação pertencem à classe de avarias particulares ou simples. Excetua-se o único caso em que o navio, para evitar dano maior de uma abalroação iminente, pica as suas amarras, e abalroa a outro para sua própria salvação (art. 764).

Colisão é o choque da embarcação e seus acessórios contra qualquer objeto que não seja considerado uma embarcação ou, ainda, contra pessoa.

Encalhe é o contato das obras vivas (parte do costado que fica submersa) de uma embarcação com o fundo do mar, provocando resistências externas que dificultam ou impedem a movimentação da embarcação. Pode ser entendido como o choque do costado do navio no mar, de forma não intencional. $O$ encalhe pode ser momentânea ou permanentemente, e a regra é que se configure como avaria simples.

Varação é ato deliberado de fazer encalhar ou por em seco a embarcação, para evitar que evento mais danoso sobrevenha. Assim é o encalhe intencional, praticado razoavelmente, em face de risco real e eminente. Dessa forma, a varação pode configurar avaria grossa.

Alijamento pode ser entendido como o ato deliberado de lançar na água, no todo ou em parte, carga ou outros bens existentes a bordo, com a finalidade de salvar a embarcação, parte da carga ou outros bens. Ressalta-se que o alijamento já foi tratado no Capítulo dessa obra que trata do Direito Ambiental Marítimo, e pode se constituir como ato de poluição marinha.

Incêndio é conceituado como a destruição provocada pela ação do fogo por combustão dos materiais de bordo, ou sobre as águas, em decorrência de 
derramamento de combustível ou inflamável, curto-circuito elétrico, guarda ou manuseio incorretos de material inflamável ou explosivo. A regra é que o incêndio por decorrer de fatos da tripulação seja considerado como uma avaria simples.

Água aberta pode ser entendida como a abertura nas aguas vivas de uma embarcação (parte submersa do costado) que permita o ingresso descontrolado de água nos espaços internos, ou a descarga de líquidos dos tanques, por fissura no chapamento, entre outros fatores.

Arribada é a mudança de rota ou de viagem que acarreta a entrada em um porto não prevista na escala ou o regresso ao ponto de partida sem efetuar a viagem iniciada. Ou seja, é a embarcação ingressar em porto ou lugar não previsto para a travessia, que não seja local de escala programada ou porto de destino. Destaca-se que o Código Comercial traz um rol exemplificativo de hipóteses de arribada justificada e injustificada.

Por último, naufrágio é a submersão total ou parcial da embarcação em águas, por perda de flutuabilidade, decorrente de embarque de água em seus espaços internos, sem possibilidade de reinserção por meios próprios. A emersão é a técnica de salvamento que permite a reflutuação do navio, mesmo totalmente afundado. Ressalta-se que o naufrágio deliberado pode se constituir como uma ato de poluição marinha, como o alijamento.

No que concerne ao naufrágio, destaca-se a Lei $n^{\circ} 7.542$, de 26 de setembro de 1986, a qual será melhor abordada neste artigo, a qual dispõe sobre a pesquisa, exploração, remoção e demolição de coisas ou bens afundados, submersos, encalhados e perdidos em águas sob jurisdição nacional, em terreno de marinha e seus acrescidos e em terrenos marginais, em decorrência de sinistro, alijamento ou fortuna do mar, e dá outras providências, e revogou o Título IX (do naufrágio e salvados), do Código Comercial. 


\title{
3 DA RESPONSABILIDADE CIVIL OBJETIVA APLICADA À REMOÇÃo DE CASCO NAUFRAGADO
}

Considerando que o objeto central deste artigo é a análise da responsabilidade pela remoção do casco naufragado, importante esclarecer incialmente o tipo de responsabilidade que deve ser reconhecida.

Destaca-se, incialmente, a Lei $n^{0} 7.542$, de 26 de setembro de 1986, a qual dispõe sobre a pesquisa, exploração, remoção e demolição de coisas ou bens afundados, submersos, encalhados e perdidos em águas sob jurisdição nacional, em terreno de marinha e seus acrescidos e em terrenos marginais, em decorrência de sinistro, alijamento ou fortuna do mar, e dá outras providências.

De acordo com a referida norma, em seu art. $5^{\circ}$ :

\begin{abstract}
Art. 5o A Autoridade Naval, a seu exclusivo critério, poderá determinar ao responsável por coisas ou bens, referidos no art. 1ํ desta lei, sua remoção ou demolição, no todo ou em parte, quando constituírem ou vierem a constituir perigo, obstáculo à navegação ou ameaça de danos a terceiros ou ao meio ambiente.
\end{abstract}

Ou seja, a remoção do casco naufrago deverá seguir a teoria da responsabilidade objetiva quando se constituir como uma obrigação determinada pela Autoridade Marítima por se estabelecer como um obstáculo à navegação ou ameaça de danos a terceiros ou ao meio ambiente.

Igualmente, neste caso, o naufrágio poderá se constituir como uma ameaça ao meio ambiente, ou seja, um ato de poluição ambiental. Desta forma, destaca-se a Política Nacional do Meio Ambiente (PNMA), que traz o conceito de degradação e de poluição ambiental, sendo a primeira a alteração adversa das características do meio ambiente; e, por sua vez, a poluição, a degradação da qualidade ambiental resultante de atividades que direta ou indiretamente prejudiquem a saúde, a segurança e o bemestar da população, criem condições adversas às atividades sociais e econômicas, afetem desfavoravelmente a biota ou as condições estéticas ou sanitárias do meio ambiente e lancem matérias ou energia em desacordo com os padrões ambientais estabelecidos. 
Por sua vez, a poluição marinha foi conceituada pela Convenção Montego Bay, em seu art. 1ํ, Decreto $n^{\circ} 1.530$, de 22 de junho de 1995, e deve ser entendida como:

\begin{abstract}
A introdução pelo homem, direta ou indiretamente, de substâncias ou de energia no meio ambiente marinho, incluindo estuários, sempre que a mesma provoque ou possa vir a provocar efeitos nocivos, tais como danos aos recursos vivos e à vida marinha, riscos à saúde do homem, entraves às atividades marítimas, incluindo a pesca e outras utilizações legítimas do mar, alteração na qualidade da água do mar, no que se fere à sua utilização e deteriorização dos locais de recreio. (G.N.).
\end{abstract}

A Constituição da República Federativa do Brasil de 1988, institui em seu art. 225, § $3^{\circ}$, a responsabilidade tripla em decorrência do dano ambiental, através da responsabilidade civil, administrativa e penal; ainda, em seu parágrafo $2^{\circ}$, estabelece que aquele que "explorar recursos minerais fica obrigado a recuperar o meio ambiente degradado, de acordo com solução técnica exigida pelo órgão público competente, na forma da lei".

Nesse diapasão, a Política Nacional do Meio Ambiente impõe ao poluidor o dever de reparação do bem ambiental, conforme se depreende do art. 4ㅜㅗ ,inciso VII, da Lei $n^{\circ}$ 6.938/81, que estabelece que a Política Nacional do Meio Ambiente visará à imposição, ao poluidor e ao predador, da obrigação de recuperar e/ou indenizar os danos causados e, ao usuário, da contribuição pela utilização de recursos ambientais com fins econômicos.

A responsabilidade civil ambiental, por força da Política Nacional do Meio Ambiente (Lei nº 6.938 , de 31 de agosto de 1981), é objetiva por risco integral, não sendo necessário perquirir culta ou causas excludentes de responsabilidade.

Em seguida, disciplina o artigo $14, \S 1^{\circ}$, sem prejuízo das penalidades definidas pela legislação federal, estadual e municipal, o não cumprimento das medidas necessárias à preservação ou correção dos inconvenientes e danos causados pela degradação da qualidade ambiental é o poluidor obrigado, independentemente da existência de culpa, a indenizar ou reparar os danos causados ao meio ambiente e a terceiros, afetados por sua atividade. Instituindo, assim, a responsabilidade objetiva, como anteriormente visto. 
O Superior Tribunal de Justiça (STJ) adota a teoria objetiva por risco integral à responsabilidade civil por danos ao meio ambiente, conforme jurisprudência infra colacionada:

\begin{abstract}
Para fins do art. 543-C do Código de Processo Civil: a) a responsabilidade por dano ambiental é objetiva, informada pela teoria do risco integral, sendo o nexo de causalidade o fator aglutinante que permite que o risco se integre na unidade do ato, sendo descabida a invocação, pela empresa responsável pelo dano ambiental, de excludentes de responsabilidade civil para afastar sua obrigação de indenizar; b) em decorrência do acidente, a empresa deve recompor os danos materiais e morais causados e c) na fixação da indenização por danos morais, recomendável que o arbitramento seja feito caso a caso e com moderação, proporcionalmente ao grau de culpa, ao nível socioeconômico do autor, e, ainda, ao porte da empresa, orientando-se o juiz pelos critérios sugeridos pela doutrina e jurisprudência, com razoabilidade, valendo-se de sua experiência e bom senso, atento à realidade da vida e às peculiaridades de cada caso, de modo que, de um lado, não haja enriquecimento sem causa de quem recebe a indenização e, de outro, haja efetiva compensação pelos danos morais experimentados por aquele que fora lesado (STJ, 2aㅡ. S., REsp 1374284/MG, Rel. Min. Luis Felipe Salomão, j. 27/08/2014, DJe 05/09/2014.).
\end{abstract}

Portanto, a PNMA estabelece a possibilidade de identificação do poluidor direto e indireto, assim o poluidor também é aquele que contribui para a poluição com consequente degradação do meio ambiente, ou seja, que assume o risco da atividade. Assim, o poluidor indireto é aquele que contribui para a degradação ambiental sem dar causa a ela de forma direta, onde, o risco da atividade caracteriza o nexo de causalidade.

Desta forma, o STJ ratifica que a responsabilidade civil por danos ambientais é objetiva e, inclusive, solidária de todos os agentes que obtiveram proveito da atividade que resultou no dano ambiental (STJ, $2^{\mathrm{a}}$ T., Aglnt no AREsp 277.167/MG, Rel. Min. Og Fernandes, j. 14/03/2017, DJe 20/03/2017.). Quanto a este ponto, importante posição de Herman Benjamin, o qual esclarece que o dano ambiental, como de resto em outros domínios, pode ser resultado de várias causas concorrentes, simultâneas ou sucessivas, dificilmente tendo uma única e linear fonte, assim é desafiador relacionar causa e efeito na maioria dos problemas ambientais (BENJAMIN, 1998, p.5-22). 
A responsabilidade solidária entre os poluidores é pautada na teoria do risco profissional, prevista no artigo 927, parágrafo único, do Código Civil, segundo a qual todos aqueles que se dediquem ao exercício de atividade com habitualidade que, por sua natureza, implique risco para os direitos de outrem, devem responsabilizar-se, independentemente de culpa, pelos danos causados.

Portanto, caso o naufrágio se caracterize como um obstáculo à navegação ou ameaça de danos a terceiros ou ao meio ambiente deve ser aplicada a responsabilidade civil objetiva para o salvamento e remoção do casco naufragado.

Entretanto, tal obrigação não se confunde com a responsabilidade administrativa marítima, conforme atuação do Tribunal Marítimo, a seguir abordada.

\section{DA RESPONSABILIDADE ADMINISTRATIVA SUBJETIVA EM FACE DO NAUFRÁGIO - ACIDENTE DA NAVEGAÇÃO}

Importante esclarecer que naufrágio é um acidente da navegação, conforme estabelece a Lei $n^{\circ} 2.180 / 1954$, que dispõe sobre o Tribunal Marítimo, e traz um rol exemplificativo dos acidentes da navegação.

Compete a Autoridade Marítima, a Capitania dos Portos e Costa de Pernambuco, nos termos da Lei $n^{\circ}$ 9.537/1997, apurar os acidentes e fatos da navegação, sendo vedada a aplicação de punição até o julgamento pelo Tribunal Marítimo, vide:

Art. 33. Os acidentes e fatos da navegação, definidos em lei específica, aí incluídos os ocorridos nas plataformas, serão apurados por meio de inquérito administrativo instaurado pela autoridade marítima, para posterior julgamento no Tribunal Marítimo. Parágrafo único. Nos casos de que trata este artigo, $\underline{e}$ vedada a aplicação das sanções previstas nesta Lei antes da decisão final do Tribunal Marítimo, sempre que uma infração for constatada no curso de inquérito administrativo para apurar fato ou acidente da navegação, com exceção da hipótese de poluição das águas. (G.N.).

O Tribunal Marítimo se consubstancia como órgão de atuação administrativa, não integrante do Poder Judiciário, sendo disciplinado pela Lei nº 2.180 , de 05 de 
fevereiro de 1954, que estabelece ser, o referido Tribunal, órgão, autônomo, auxiliar do Poder Judiciário, com atribuições de julgar os acidentes e fatos da navegação marítima, fluvial e lacustre e as questões relacionadas com tal atividade, e com jurisdição em todo o território nacional. O Tribunal Marítimo é formado por sete juízes civis e militares, com jurisdição em todo o território nacional (CAMPOS, 2011, p.179).

A jurisdição do Tribunal Marítimo se estende sobre todo o território nacional e alcança toda pessoa jurídica ou física envolvida, por qualquer força ou motivo, em acidentes ou fatos da navegação, respeitados os demais instrumentos de Direito Interno e as normas do Direito Internacional (CAMPOS, 2011, p.103).

Dessa forma, a jurisdição desse tribunal pode ser contenciosa e voluntária. No que tange à jurisdição voluntária o Tribunal Marítimo atuará na seara administrativa de expediente, como por exemplo, com expedição de certidões. Já na jurisdição contenciosa a corte marítima em comento atua como órgão julgador dos acidentes marítimos e fatos da navegação, onde se destacam o processo administrativo punitivo e processo administrativo disciplinar.

Destarte, a competência e jurisdição de maior relevância é a de julgar os acidentes e fatos da navegação, como estabelece a Lei nº 2.180/1954, em seu artigo 13 (treze), determinando as especificidades de cada caso, as circunstâncias, e até aplicando penas previstas na mesma legislação.

A teor do artigo 13, inciso I da referida lei, ao julgar os acidentes e fatos da navegação, elencados de forma exemplificativa nos artigos 14 e 15 da referida lei, o Tribunal Marítimo deverá definir a natureza, determinando as causas, circunstâncias e extensão, bem como indicar os seus responsáveis.

A Lei $n^{\circ}$ 2.180/1954 não define o que seriam os acidentes da navegação, apenas os exemplificam, em seu artigo 14, da seguinte forma: naufrágio, encalhe, colisão, abalroação, água aberta, explosão, incêndio, varação, arribada e alijamento; avaria ou defeito nas instalações do navio, que ponha em risco a embarcação, as vidas e fazendas de bordo.

Por sua vez, a Lei n².180/1954, em seu art. 15, menciona que se consideram fatos da navegação: o mau aparelhamento ou a impropriedade da embarcação para o serviço em que é utilizada, e a deficiência da equipagem; a alteração da rota; a má 
estimação da carga, que sujeite a risco a segurança da expedição; a recusa injustificada de socorro a embarcação em perigo; todos os fatos que prejudiquem ou ponham em risco a incolumidade e segurança da embarcação, as vidas e fazendas de bordo; e o emprego da embarcação, no todo ou em parte, na prática de atos ilícitos, previstos em lei como crime ou contravenção penal, ou lesivos à Fazenda Nacional.

Assim, destaca-se que a responsabilidade administrativa marítima segue a teoria da responsabilidade subjetiva, não havendo espaço para responsabilidade objetiva, devendo-se perquirir a existência concomitante de dano, nexo causal e dolo ou culpa.

Neste sentido preceitua o Art. 186, do Código Civil, vide: "Aquele que, por ação ou omissão voluntária, negligência ou imprudência, violar direito e causar dano a outrem, ainda que exclusivamente moral, comete ato ilícito.".

De acordo com a Lei no 2180/1954, art. 17, “a”, na apuração da responsabilidade por fatos e acidentes da navegação, cabe ao Tribunal Marítimo investigar se o capitão, o prático, o oficial de quarto, outros membros da tripulação ou quaisquer outras pessoas foram os causadores por dolo ou culpa. Desta forma, a responsabilidade administrativa marítima está pautada no reconhecimento da culpa.

Conforme é possível se depreender do acordão abaixo citado para que haja condenação, sempre haverá a caracterização dos elementos caracterizadores da responsabilidade subjetiva, entre esses destaca-se a culpa, vide:

TRIBUNAL MARÍTIMO. PROCESSO № 25.713/11 ACÓRDÃO. N/M "WESTFALIA EXPRESS". Encalhe de mercante estrangeiro durante navegação no canal de acesso ao Terminal de Contêineres - TECON, porto do Rio de Janeiro, baía de Guanabara, Município do Rio de Janeiro, RJ. Sem danos ao mercante e, sem registros de acidentes pessoais ou de poluição ao meio ambiente hídrico. Erro de navegação. Condenação. ACORDAM os Juízes do Tribunal Marítimo, por unanimidade quanto ao mérito e por maioria quanto à pena dos representados, nos termos do voto da Exma. Sra. JuízaRelatora: a) quanto à natureza e extensão do acidente da navegação: encalhe de mercante estrangeiro durante navegação no canal de acesso ao terminal de Contêineres-TECON, porto do Rio de Janeiro, baía de Guanabara, município do Rio de Janeiro, RJ. Sem danos materiais e sem registro de acidentes pessoais ou poluição ao meio ambiente hídrico; b) quanto à causa determinante: erro de navegação; e c) decisão: julgar procedente a representação da Douta Procuradoria Especial da Marinha (fls. 121 a 132) e, considerando o acidente da navegação, previsto no art. 14, letra "a" da Lei n ${ }^{\circ} 2.180 / 54$ e suas consequências, como decorrente das condutas imprudente de Luiz Felippe Vieira Pereira, na condição de prático e negligente 
do CLC Conyo Ivanov Conev, este na condição de então comandante, ambos do N/M "WESTFALIA EXPRESS", condenar o $1^{\circ}$ à pena de multa no valor de $\mathrm{R} \$ 500,00$ (quinhentos reais), prevista no inciso VII e o $2^{\circ}$ à pena de repreensão, prevista no inciso I, ambos do art. $121 \mathrm{c} / \mathrm{c}$ os arts. 124, incisos I e IX e 127, todos da Lei ํo 2.180/54, com redação alterada pela Lei $n^{\circ}$ 8.969/94.

Portanto, apenas através da conclusão do Inquérito Administrativo por Fatos e Acidentes da Navegação (IAFN), e após o julgamento pelo Tribunal Marítimo será possível saber qual a real causa do acidente e se há algum culpado, para que possa se pensar em responsabilidades.

A atuação do Tribunal Marítimo não fere o acesso ao Poder Judiciário, órgão responsável pela atividade jurisdicional, posto que aquele atua de forma conjunta, com o intuito de assessoramento, bem como, nas matérias de sua competência, julga com um elevado grau de competência técnica, em respeito aos princípios constitucionais do processo (CAMPOS, 2011, p.203).

Desta forma, ressalta-se que quando se discutir em juízo questão decorrente de acidentes e fatos da navegação da competência do Tribunal Marítimo haverá suspensão do processo (art. 313, VII, CPC/15), fato esse que demonstra nitidamente a importância da atuação do tribunal em comento em questões afetas às avarias grossas.

Quanto ao reconhecimento e definição da responsabilidade marítima importante a identificação do território / espaço marítimo onde ocorreu o naufrágio, conforme a seguir analisado.

\section{REMOÇÃO DE CASO NAUFRAGADO: POSSÍVEIS RESPONSÁVEIS}

Diante da ocorrência de um naufrágio surgem possíveis responsáveis diretos para promover a remoção do casco naufrago, bem como do óleo no interior da embarcação, visando, ainda, a promoção das ações de prevenção e contenção de danos ao meio ambiente. Isto em decorrência do fato de o naufrágio causar danos direito ao meio ambiente, além de representar um risco à segurança da navegação. 
O estabelecimento da referida responsabilidade civil vai depender do local do naufrágio e se no caso haveria seguro marítimo, conforme analisado a seguir.

Preliminarmente, no Brasil há um séria de atores que podem ser responsabilizados, de acordo com o local do naufrágio.

Caso o acidente em glosa ocorra na área do porto organizado, a Lei $\mathrm{n}^{\circ}$ $12.815 / 2013^{1}$ disciplina que competente à administração do porto organizado (Autoridade Portuária) promover a remoção de embarcações ou cascos de embarcações, que possam prejudicar o acesso ao porto, vide:

Art. 17. A administração do porto é exercida diretamente pela União, pela delegatária ou pela entidade concessionária do porto organizado. § $1^{\circ}$ Compete à administração do porto organizado, denominada autoridade portuária: VII - promover a remoção de embarcações ou cascos de embarcações que possam prejudicar o acesso ao porto; (G.N.).

Todavia, quando o naufrágio ocorrer em águas jurisdicionais brasileira, este será regulado pela Lei $n^{0} 7.542 / 1986$, a qual dispõe sobre a pesquisa, exploração, remoção e demolição de coisas ou bens afundados, submersos, encalhados e perdidos em águas sob jurisdição nacional, em terreno de marinha e seus acrescidos e em terrenos marginais, em decorrência de sinistro, alijamento ou fortuna do mar, e dá outras providências.

Neste cenário, surgem então, três possíveis responsáveis, quais sejam: proprietário da embarcação, segurador e Autoridade Marítima, conforme a seguir explanado.

Deste modo, a Autoridade Marítima, a seu exclusivo critério, poderá determinar ao responsável por coisas ou bens fundados, submersos, encalhados e perdidos em águas sob jurisdição nacional, sua remoção ou demolição, no todo ou em parte, quando constituírem ou vierem a constituir perigo, obstáculo à navegação ou ameaça de danos a terceiros ou ao meio ambiente.

\footnotetext{
${ }^{1}$ Dispõe sobre a exploração direta e indireta pela União de portos e instalações portuárias e sobre as atividades desempenhadas pelos operadores portuários, e dá outras providências.
} 
Desta forma, a referida Lei menciona responsável, sem indicar diretamente quem este seria, deixando, todavia, implícito em outros artigos ${ }^{2}$, ao se referir à "perda da propriedade", o que indica ser o proprietário da coisa o primeiro responsável pela operação da remoção.

Entretanto, caso o responsável não tenha providenciado ou conseguido realizar as operações dentro dos prazos legais estabelecidos, surge a possibilidade do segundo responsável atuar, qual seja a Autoridade Marítima, confira:

Art. 10. A Autoridade Naval poderá assumir as operações de pesquisa, exploração, remoção ou demolição das coisas ou bens referidos no art. $1^{\circ}$ desta lei, por conta e risco de seu responsável, caso este não tenha providenciado ou conseguido realizar estas operações dentro dos prazos legais estabelecidos. Art. 12. A Autoridade Naval poderá empregar seus próprios meios ou autorizar terceiros para executarem as operações de pesquisa, exploração, remoção ou demolição de coisas ou bens referidos no art. $1^{\circ}$ desta lei, no exercício do direito a que se referem o art. 10 e $\circ \S 2^{\circ}$ do art. 11.

Neste interim, destaca-se a NORMAM 10/2003/DPC, Norma da Autoridade Marítima para pesquisa, exploração, remoção e demolição de coisas e bens afundados, submersos, encalhados e perdidos.

A NORMAM 10/DPC, estabelece no item 203, que quando as coisas ou bens constituírem ou vierem a constituir perigo, obstáculo à navegação ou ameaça de danos a terceiros ou ao meio ambiente, o Distrito Naval (DN) poderá adotar as seguintes linhas de ação:

a)determinar ao responsável pelas coisas ou bens submersos ou encalhados em águas sob jurisdição nacional a sua remoção ou demolição, no todo ou em parte.

b)assumir as operações de remoção, demolição ou exploração da coisa ou bem submerso ou encalhado, por conta e risco de seu proprietário ou responsável, desde que a situação vigente não esteja na competência da Administração do Porto Organizado, conforme previsto no Art. 17, $\S 1^{\circ}$, inciso VII, da Lei nº 12815/2013 a quem caberá efetuar a respectiva operação.

\footnotetext{
2 Vide: Art. $7^{\circ}$. Decorrido o prazo de 5 (cinco) anos, a contar da data do sinistro, alijamento ou fortuna do mar, sem que o responsável pelas coisas ou bens referidos no art. 1ำ desta lei tenha solicitado licença para sua remoção ou demolição, será considerado como presunção legal de renúncia à propriedade, passando as coisas ou os bens ao domínio da União.
} 
Igualmente, a referida NORMAM, em seu item 302, disciplina: "A remoção ou demolição, quando não realizadas pela União, correrá por conta e risco do interessado".

Em seguida, estabelece a Lei $n^{\circ} 7542 / 1986$, que o responsável direto para proceder a referida remoção também poderá ser a empresa seguradora:

\begin{abstract}
Art. 13. O responsável pelas coisas ou bens referidos no art. $1^{\circ}$ desta lei, seu cessionário e o segurador, que tenham coberto especificamente os riscos de pesquisa, exploração, remoção ou demolição das coisas ou bens, permanecerão solidariamente responsáveis: I - pelos danos que venham provocar, direta ou indiretamente, à segurança da navegação, a terceiros ou ao meio ambiente, até que as coisas ou os bens sejam removidos ou demolidos, ou até que sejam incorporados ao domínio da União pelo decurso do prazo de 5 (cinco) anos a contar do sinistro; II - pelo que faltar para reembolsar ou indenizar a União, quando a Autoridade Naval tiver atuado conforme disposto no art. 10 e no $\S 2^{\circ}$ do art. 11. (G.N)
\end{abstract}

Conforme se depreende do Art. 13 retro-citado, ressalta-se que a Lei menciona de forma clara que o segurador é aquele que tenha coberto de forma específica a remoção do casco naufragado, e que está será solidariamente responsável pelos possíveis danos decorrentes do naufrágio.

O que deve ser ponderado no caso em concreto é que em decorrência do naufrágio os destroços podem representar um risco ou um dano ambiental, a depender do local do afundamento e, caso isso ocorra, estaríamos diante do dever de salvamento / remoção em virtude da responsabilidade civil objetiva.

O Seguro Marítimo é definido pelo Código Comercial Brasileiro, no art. 666, como o contrato:

[...] pelo qual o segurador, tomando sobre si a fortuna e riscos do mar, se obriga a indenizar ao segurado da perda ou dano que possa sobrevir ao objeto do seguro, mediante um prêmio ou soma determinada, equivalente ao risco tomado, só pode provar-se por escrito, a cujo instrumento se chama apólice; contudo julga-se subsistente para obrigar reciprocamente ao segurador e ao segurado desde o momento em que as partes se convierem, assinando ambas a minuta, a qual deve conter todas as declarações, cláusulas e condições da apólice.

Inicialmente, é necessário esclarecer a diferença entre indenização, pelo valor coberto na apólice, das despesas de salvamento, que gera o dever de ressarcimento 
ao segurado (indenização \# ressarcimento).

A responsabilização por danos a terceiros (responsabilidade civil) não se confunde com despesas com salvamento. Desta forma, a cobertura de salvamento é obrigação que decorre de dispositivo legal, qual seja o Código Civil, confira:

Art. 771. Sob pena de perder o direito à indenização, o segurado participará o sinistro ao segurador, logo que o saiba, e tomará as providências imediatas para minorar-lhe as consequências. Parágrafo único. Correm à conta do segurador, até o limite fixado no contrato, as despesas de salvamento consequente ao sinistro.

Por sua vez, o art. 779 do Código Civil, completa o regime da reparação devida ao segurado dispondo que o risco de danos garantido pelo contrato de seguro compreende "todos os prejuízos resultantes ou consequentes, como sejam os estragos ocasionados para evitar o sinistro, minorar o dano ou salvar a coisa".

Igualmente o faz o Código Comercial:

Art. 710 - São a cargo do segurador todas as perdas e danos que sobrevierem ao objeto seguro por alguns dos riscos especificados na apólice. Art. 730 - O segurador é obrigado a pagar ao segurado as indenizações a que tiver direito, dentro de 15 (quinze) dias da apresentação da conta, instruída com os documentos respectivos; salvo se o prazo do pagamento tiver sido estipulado na apólice.

Outrossim, no caso de naufrágio, disciplina o Código Comercial, o segurado deve tomar todas as medidas necessárias para salvar ou reclamar os objetivos segurador, podendo, inclusive, exigir o adiantamento do dinheiro necessário, vide:

Art. 721 - Nos casos de naufrágio ou varação, presa ou arresto de inimigo, o
segurado é obrigado a empregar toda a diligência possível para salvar ou
reclamar os objetos seguros, sem que para tais atos se faça necessária a
procuração do segurador, do qual pode o segurado exigir o adiantamento do
dinheiro preciso para a reclamação intentada ou que se possa intentar, sem
que o mau sucesso desta prejudique ao embolso do segurado pelas
despesas ocorridas.

O Prof. Norman A. Martínez Gutiérrez (2012, p.169), a respeito da cobertura de remoção de destroços, ensina: 
Thus, is frequently the case that the shipowner and his P\&I Club will voluntarily undertake the removal of the wreck. Indeed standard form contracts for this purpose, such as the WRECKFIZED, WRECKHIRE, WRECKSTAGE, have been produced by the ISU, the international Group of P\&I Clubs and other interested parties. There forms have been endorsed and published by BINCO.

Neste sentido, explica Humberto Theodoro Junior (2014):

Diante do sinistro, como se vê, o segurador torna-se (ou pode tornar-se) responsável por duas obrigações distintas e oriundas de fontes diversas: (i) a de pagar a indenização correspondente ao sinistro objeto da cobertura contratada (obrigação contratual, portanto); e (ii) a de suportar as despesas de salvamento - se as houver, obviamente -, respeitado o "limite fixado no contrato". Aqui a obrigação já não é mais produto do contrato, mas da lei, que a institui, de maneira originária, haja ou não previsão no contrato a seu respeito. $O$ que fica relegado à vontade convencional das partes é apenas o estabelecimento do limite das despesas ressarcíveis, e nunca a existência propriamente da obrigação do segurador de responder por tais encargos. Repita-se: não é o contrato que cria tal responsabilidade, é a própria lei que a institui e a imputa ao segurador. Tratase, assim, de obrigação tipicamente legal, e não contratual ou convencional.

Desta forma, o segurado, quando efetua os gastos de salvamento do bem afetado pelo sinistro, o faz compelido também por imposição da lei e sob a cominação de perda do direito à indenização securitária (CC, art. 771, caput) (THEODORO JÚNIOR, 2014).

Tão somente dessa maneira, o contrato de seguro em tela poderá atingir a sua função social, perfeitamente definida pelo advogado Dr. Ernesto Tzirulnik:

\begin{abstract}
Assim, a função social do seguro revela-se de forma cristalina: garantir, com o auxílio de muitos, que a desorganização que atingiu a uns poucos possa ser superada. Satisfaz-se o interesse de todo o "sistema" em questão, uma vez que as relações podem continuar a se desenvolver, de tal forma que praticamente não sejam sentidas as consequências do ocorrido (TZIRULNIK; OCTAVIANI, 2000, p.11-43).
\end{abstract}

Além do mais, é certo que os contratos de seguro são fundados no risco. Tanto que cabe ao segurado transferir a propriedade do objeto segurado à seguradora nos casos de perda total construtiva ou presumida, em troca do pagamento da indenização por perda total, conforme institui o Código Comercial Brasileiro, vide: 
CCOm. Art. 753 - É lícito ao segurado fazer abandono dos objetos seguros, e pedir ao segurador a indenização de perda total nos seguintes casos: 1 presa ou arresto por ordem de potência estrangeira, 6 (seis) meses depois de sua intimação, se o arresto durar por mais deste tempo; 2 - naufrágio, varação, ou outro qualquer sinistro de mar compreendido na apólice, de que resulte não poder o navio navegar, ou cujo conserto importe em três quartos ou mais do valor por que o navio foi segurado; 3 - perda total do objeto seguro, ou deterioração que importe pelo menos três quartos do valor da coisa segurada (artigo n`s 759 e 777); 4 - falta de notícia do navio sobre que se fez o seguro, ou em que se embarcaram os efeitos seguros (artigo $\mathrm{n}^{\circ} .720$ ).

Neste interim, importante mencionar Convenção Internacional de Nairobi para Remoção de Destroços de 2007, que ainda está em processo de adesão pelo Brasil, entretanto que garante o direito de qualquer Estado soberano, parte da convenção, de promover diretamente a remoção de destroços.

O Prof. Norman A. Martínez Gutiérrez (2012. p. 167), a respeito da referida convenção, ensina:

The original of the Nairobi convention date back to the 1970s. Indeed, the
initial trigger seems to have been the Torrey Canyon incident in 1967. As
started above, this incident led to the creation of the IMO Legal Committee
and the adoption of the 1969 CLC and Fund Convention. Nevertheless,
considering that the wreck of the Torrey Canyon lay outside the limits of the
UK territorial sea, and measures were required to prevent damage to the coast
by oil which continued to leak from the wreck, it became clear that as
international convention was required to grant coastal States powers to take
such measures on the high seas. This led to the adoption of the International
Convention.

A referida Convenção reconhece que os destroços, se não removidos, podem representar um risco para a navegação ou para o meio ambiente marinho, e que é importante a adoção de regras e procedimentos internacionais uniformes para assegurar a pronta e efetiva remoção de destroços e o pagamento de compensação pelos custos envolvidos na remoção.

Destaca-se que a Convenção em glosa só deve ser aplicada quando os destroços representam um risco ("It must be noted that if the wreck does not constitute a hazard, the Convention does not aply") (GUTIÉRREZ, 2012. p. 170).

A Convenção Internacional de Nairobi se aplica em naufrágios ocorridos em Zona Econômica Exclusiva de um Estado Parte, estabelecida de acordo com o direito internacional ou, se um Estado Parte não tiver estabelecido tal zona, uma área além 
e adjacente do mar territorial daquele Estado, determinada pelo Estado de acordo com o direito internacional e estendendo-se por não mais de 200 milhas náuticas contadas a partir das linhas de base das quais é medida a largura do seu mar territorial.

Em seu art. $2^{\circ}$, a referida Convenção, estabelece que: "A aplicação desta Convenção dentro da área da Convenção não dará a um Estado Parte o direito de pleitear ou de exercer soberania, ou direitos soberanos sobre qualquer parte do altomar."

A Convenção Internacional de Nairobi para Remoção de Destroços, 2007, ratifica, como regra, no art. 10, a responsabilidade do proprietário pelos custos de localização, sinalização e remoção dos destroços. Ainda, a obrigação de seguro ou garantia financeira para remoção de destroços para navios com arqueação bruta de 300 ou mais toneladas.

Os custos com remoção de destroços / casco naufragado são considerados como despesas com salvamento, o que possibilita uma atuação incisiva dos possíveis responsáveis.

Restou esclarecido que remoção do casco naufrago só deve ser uma obrigação quando determinado pela Autoridade Marítima e quando constituir ou vier a constituir perigo, obstáculo à navegação ou ameaça de danos a terceiros ou ao meio ambiente (art. $5^{\circ}$, da Lei ${ }^{\circ} 7.542 / 1986$ ). Assim, a permanência do casco no local de naufrágio é uma solução viável e já aceita pela referida lei.

Diante da impossibilidade completa de remoção do casco naufragado, deve ser reconhecida como solução viável a permanência do casco no local do naufrágio. Para tanto, medidas preventivas para evitar danos ambientais e promover a segurança da navegação devem ser tomadas, com destaque a remoção do óleo no interior do casco, com vistas a manter a qualidade ambiental e a segurança.

Além da necessária manifestação da Autoridade Marítima, conforme estipula a Lei $n^{\circ}$ 9.537/1997, que deverá emitir um parecer da Autoridade Marítima no que concerne ao ordenamento do espaço aquaviário e à segurança da navegação, observando os procedimentos preconizados nas Normas da Autoridade Marítima, é imprescindível manifestação do órgão ambiental federal competente, qual seja o Instituto Brasileiro do Meio Ambiente e dos Recursos Naturais (IBAMA). 
Quando estamos diante de um naufrágio deliberado adota-se como referência a Instrução Normativa nº 22 de 10/07/2009 / IBAMA, que dispõe sobre o licenciamento ambiental para instalação de recifes artificiais no Mar Territorial na Zona Econômica Exclusiva brasileiros.

Destaca-se que a referida IN foi elaborada considerando a Convenção sobre Prevenção da Poluição Marinha por Alijamento de Resíduos e Outras Matérias (Convenção de Londres - LC/72), internalizada no Brasil pelo Decreto ํㅜ 87.566, de 16 de setembro de 1982, que considera por "alijamento" todo despejo deliberado, no mar, de resíduos e outras substâncias efetuado por embarcações, aeronaves, plataformas ou outras construções no mar; e todo afundamento deliberado, no mar, de embarcações, aeronaves, plataformas ou outras construções no mar. Ainda, por "mar" se entendem todas as águas marinhas que não sejam águas interiores dos Estados.

Assim, a Instrução Normativa n $n^{\circ} 2$ de 10/07/2009 não se aplica aos casos onde se analisa o naufrágio acidental, onde a permanência / abandono da embarcação no local de naufrágio finda por ser a única saída possível.

Nesta senda, menciona-se o Artigo V da Convenção de Londres - LC/72, o qual estabelece que as proibições de alijamento (Artigo IV) não se aplicarão quando for necessário salvaguardar a segurança da vida humana ou de embarcações, aeronaves, plataformas e outras construções no mar, em casos de força maior devidos às inclemências do tempo ou em qualquer outro caso que constitua perigo para a vida humana ou uma real ameaça para as embarcações, aeronaves, plataformas ou outras construções no mar, se o alijamento configurar o único meio de se evitar a ameaça e se existir toda probabilidade de que os danos oriundos do dito alijamento venham a ser menores do que os que de outro modo ocorreriam.

Desta forma, o alijamento será levado a cabo de forma que se reduza ao mínimo a probabilidade de que venha a ocasionar danos a seres humanos ou à vida marinha.

No caso de naufrágios acidentais não se fala em licenciamento ambiental, considerando que o ato já ocorreu, devendo o referido órgão analisar e indicar estudos 
e medidas mitigadoras de possíveis danos ambientais, que ficarão a cargo dos possíveis responsáveis, conforme explicado acima.

No mais, a questão afeta à responsabilidade civil de diversos atores ou até o reconhecimento da necessária permanência do casco no local de naufrágio se coaduna como um caso de difícil solução.

Assim, no caso em concreto diversos cenários e soluções devem ser considerados visando a obtenção de uma solução adequada. Tal aspecto merece ser amplamente considerado posto que por vezes acidentes marítimos, com destaque à naufrágios, são judicializados.

Nessas ações, como pedido liminar há sempre a remoção do caso naufragado em curtíssimo período de tempo, sem que haja um conhecimento acerca da realidade das condições operacionais, ambientais e estruturais do referido salvamento.

Conforme ensina Ronald Dworkin certos conceitos jurídicos, como os de contrato válido, responsabilidade civil e crime, têm a seguinte característica: se o conceito é válido em determinada situação, os juízes têm o dever, pelo menos prima facie, de decidir certos pleitos num certo sentido, mas se não é válido, os juízes devem, prima facie, decidir os mesmos pleitos no sentido oposto (DWORKIN, 2000, p.190).

Assim, nesses casos não se supõe que exista alguma terceira possibilidade, que no caso de naufrágios, no qual pode ser inclusive a permanência do casco no local onde se encontre, quando não é possível a sua remoção ou quando não restou configurado perigo, obstáculo à navegação ou ameaça de danos a terceiros ou ao meio ambiente.

Conforme ensina Dworkin, "A lei pode estipular, de maneira similar, circunstâncias em que alguém que causou dano não é responsável nem não responsável por esse dano, mas, como poderíamos dizer, 'vulnerável à responsabilidade." (DWORKIN, 2000, p.192).

Portanto, diante do caso concreto, a solução aceitável e necessária poderá ser a permanência do casco no local do naufrágio, devendo existir uma interpretação ampla, considerando uma terceira possibilidade de solução. 


\section{CONCLUSÃO}

Conforme anunciado inicialmente, o objetivo principal deste trabalho é a problemática subjacente à definição da responsabilidade civil pela remoção dos cascos naufragados, possibilitando uma maior proteção da área marítima, evitando danos ambientais e pugnado pela manutenção da segurança da navegação.

Desta forma, através do artigo em comento, foi possível se atingir as conclusões a seguir indicadas.

A remoção do casco naufrago deverá seguir a teoria da responsabilidade civil objetiva quando se constituir como uma obrigação determinada pela Autoridade Marítima, por se estabelecer como um obstáculo à navegação ou ameaça de danos a terceiros ou ao meio ambiente.

Importante elucidar que naufrágio é um acidente da navegação, conforme estabelece a Lei $n^{\circ}$ 2.180/1954, que dispõe sobre o Tribunal Marítimo, sendo conceituado como a submersão total ou parcial da embarcação em águas, por perda de flutuabilidade, decorrente de embarque de água em seus espaços internos, sem possibilidade de reinserção por meios próprios.

A teor do artigo 13, inciso I da referida lei, ao julgar os acidentes e fatos da navegação, Tribunal Marítimo deverá definir a natureza, determinando as causas, circunstâncias e extensão, bem como indicar os seus responsáveis, assim poderá se estabelecer a responsabilidade administrativa subjetiva marítima.

Diante da ocorrência de um naufrágio surgem possíveis responsáveis para promover a remoção do casco naufrago, bem como do óleo no interior da embarcação, visando, ainda, a promoção das ações de prevenção e contenção de danos ao meio ambiente.

Portanto, caso o acidente em glosa ocorra na área do porto organizado, a Lei $n^{\circ} 12.815 / 2013$ disciplina que competente à administração do porto organizado (Autoridade Portuária) promover a remoção de embarcações ou cascos de embarcações, que possam prejudicar o acesso ao porto. Todavia, quando o naufrágio ocorrer em águas jurisdicionais brasileira, este será regulado pela Lei n ${ }^{\circ}$.542/1986, a qual dispõe sobre a pesquisa, exploração, remoção e demolição de coisas ou bens 
afundados, submersos, encalhados e perdidos em águas sob jurisdição nacional, em terreno de marinha e seus acrescidos e em terrenos marginais, em decorrência de sinistro, alijamento ou fortuna do mar, e dá outras providências. Neste cenário, surgem, então, três possíveis responsáveis, quais sejam: proprietário da embarcação, segurador e Autoridade Marítima.

Restou esclarecido que remoção do casco naufrago só deve ser uma obrigação quando determinado pela Autoridade Marítima e quando constituir ou vier a constituir perigo, obstáculo à navegação ou ameaça de danos a terceiros ou ao meio ambiente (art. $5^{\circ}$, da Lei $n^{\circ} 7.542 / 1986$ ). Assim, a permanência do casco no local de naufrágio é uma solução viável e já aceita pela referida lei.

Diante da impossibilidade completa de remoção do casco naufragado, deve ser reconhecida como solução viável a permanência do casco no local do naufrágio. Para tanto, medidas preventivas para evitar danos ambientais e promover a segurança da navegação devem ser tomadas, com destaque a remoção do óleo no interior do casco, com vistas a manter a qualidade ambiental e a segurança.

Quando estamos diante de um naufrágio deliberado, intencional, adota-se como referência a Instrução Normativa n ${ }^{\circ} 22$ de 10/07/2009 / IBAMA, que dispõe sobre o licenciamento ambiental para instalação de recifes artificiais no Mar Territorial na Zona Econômica Exclusiva brasileiros. Entretanto, a referida a Instrução Normativa não se aplica aos casos onde se analisa o naufrágio acidental, onde a permanência / abandono da embarcação no local de naufrágio finda por ser a única saída possível.

Portanto, nesses casos a permanência do casco no local do naufrágio, quando não é possível a sua remoção ou quando não restou configurado perigo, obstáculo à navegação ou ameaça de danos a terceiros ou ao meio ambiente, pode findar por ser uma possível solução, devendo, para tanto, existir uma interpretação ampla, considerando todas as reais possibilidades de solução dos conflitos.

\section{REFERÊNCIAS}

BENJAMIN, Antônio Herman de Vasconcellos e. Responsabilidade civil pelo dano ambiental. Revista de Direito Ambiental. v. 9/1998. 
BRASIL. Agência Brasil. Acidentes com embarcações no Brasil aumentam 12,63\% em 2017. Disponível em: <http://agenciabrasil.ebc.com.br/geral/noticia/201708/acidentes-com-embarcacoes-no-brasil-aumentam-1263-em-2017>. Acesso em 05 de mai. 2018.

. CMAR - Comando da Marinha. Estatísticas de acidentes marítimos no Brasil. Acesso à informação. 13/05/2016. Disponível em: <http://www.consultaesic.cgu.gov.br/busca/dados/Lists/Pedido/ltem/displayifs.aspx?L ist=0c839f31\%2D47d7\%2D4485\%2Dab65\%2Dab0cee9cf8fe\&ID=479126\&Web=88c c5f44\%2D8cfe\%2D4964\%2D8ff4\%2D376b5ebb3bef>. Acesso em 05 de mai. 2018.

. DPC. Quadros Estatísticos de Inquéritos e Acidentes da Navegação (IAFNs), 2018. Disponível em: <https://www.dpc.mar.mil.br/pt-br/diian/estatisticas-deacidientes/acidentes-em-2018>. Acesso em 05 de mai. 2018.

CAMPOS, Ingrid Zanella Andrade. Curso de Direito Marítimo Sistematizado Direito Material e Processual. Curitiba: Juruá, 2017.

. Direito constitucional marítimo. Curitiba: Juruá, 2011.

DWORKIN, Ronald. Uma questão de princípio. Tradução Luís Carlos Borges. - São Paulo: Martins Fontes, 2000. - (Justiça e direito).

GOMES, Luiz Flávio; VIGO, Luis Rodolfo. Do Estado de direito constitucional e transconstitucional: riscos e precauções (navegando pelas ondas evolutivas do Estado e da justiça. São Paulo: Premier Máxima, 2008.

GUTIÉRREZ, Norman A. Martínez. Limitation of liability in international maritime conventions: the relationship between global limitation convention and particular limitation regimes. New York: Routledge, 2012.

THEODORO JUNIOR, Humberto. Seguro de Danos - Despesas de Salvamento e Despesas de Contenção: Regime Jurídico. 2014. Disponível em <http://www.lex.com.br/doutrina_26663422_SEGURO_DE_DANOS_DESPESAS_D E_SALVAMENTO_E_DESPESATS_DE_CONTENCAO_REGIME_JURIDICO.aspx>.

TZIRULNIK, Ernesto; OCTAVIANI, Alessandro. Fraude contra o Seguro. São Paulo: Revista dos Tribunais. Vol 772/2000, p. 11-43. 